\title{
Features of Creativity as Expressed in the Construction of New Analogical Problems by Intellectually Gifted Students
}

\author{
Rama Klavir ${ }^{1}$, Malka Gorodetsky ${ }^{2}$ \\ ${ }^{1}$ The Governmental Excellence Program in the Colleges of Education, \\ and The Kaye College of Education, Beer-Sheva, Israel; \\ ${ }^{2}$ Department of Education, Ben-Gurion University, Beer-Sheva, Israel. \\ Email: Rama_k@macam.ac.il,malka@bgu.ac.il \\ Received April 7h, 2011; revised May 10 $0^{\text {th }}$, 2011; accepted May 22 ${ }^{\text {nd }}, 2011$.
}

\begin{abstract}
The present research attempts to provide empirical data on creativity features that were employed by gifted students, as compared to "regular" ones, in the process of constructing analogical problems. The research is coping with two major components of creativity: a) Readiness to get involved in the construction of new analogical problems and b) Creative features in the constructed problems. The results indicate that: 1) Gifted students were more creative than their age peers on the dimensions that were defined as relative creativity. 2) Relative creativity was especially salient in tasks that involved insight thinking. 3) Despite the high relative creativity of the gifted students' their comparative creativity, i.e. their creative capabilities as compared to the optimum, were limited. The results are coherent with the need and recommendations for progressive nurturing of gifted students towards fulfilling their creative potential.
\end{abstract}

Keywords: Intellectual Giftedness, Relative Creativity, Comparative Creativity, Construction of Analogical Problems, Readiness to Become Creative, Features of Creative Products

\section{Introduction}

The research literature regarding intellectually gifted children (high IQ) addresses creativity (e.g. Rogers, 2002: p. 36; Mulhern, 2003; Rogers \& Silverman, 1998) and divergent thinking as salient and unique attributes of these children. However, the connection between intellectual giftedness and creativity seems to lack conclusive data. Nevo (1997) states a correlation of only 0.32 between creativity and intelligence and justifies this low correlation by suggesting that a high IQ is probably a necessary condition for creativity but not a sufficient one. Similarly, Tannenbaum (1983) in his review of the creativity literature till the 80 s, states that the correlation between creativity scores and IQ-s of gifted children vs. "regular" populations, is ranging from near-zero to high significance. Observations made by VanTassel-Baska (2001) more than twenty years later led her to the conclusion: "creativity is an elusive factor in its relationship to giftedness".

Indeed, this confusing picture can also be found in the review by Milgram \& Livne (2006) regarding creativity in Israel. They address two articles that originated from the same Israeli research group (Landau, 1981; Landau \& Wiessler, 1998). The 1981 study reports that the correlation between intelligence (high-IQ) and creativity of gifted, as compared to non-gifted high school students, was found to be zero whereas, the 1998 study that uses different measures for creativity of gifted children (fluency and flexibility: Torrance's Circles subset from 1972), reported a positive correlation between intellectual giftedness and creativity.

The source for these inconsistencies may stem from a mystified connection between giftedness and creativity or it may be the result of the composite nature of creativity which makes its assessment difficult (Feldman 1999; Hennessey, 2004; Sternberg \& Lubart, 1996).

This complexity may be due to the multifacedness of the creativity components and their interrelationships. For example, Barron (1988) suggests a model of creativity that is based on " $a$ creative product, produced by a creative person as a result of a creative process", i.e. creativity involves a personal features (e.g. motivation), a process (e.g. the cognitive processes) and the nature of the creative product. A fourth component that relates to the context of creativity was added by other researchers in this field (Kleiman, 2005; Plucker \& Beghetto 2004; Sternberg and Lubart, 1996). The latter was termed as the Press component (Basadur \& Hausdorf, 1996) and it emphasizes the connection and dependence of the creative individual on the unique context (Csikszentmihalyi, 1988), and the activities she/he addresses (De Souza, 2000).

The ambiguity as to the connection between creativity and giftedness may stem from other difficulties in the process of creativity assessment. The features of a creative person are not easily accessible (Kleiman, 2005) and the nature of the creative thinking processes can be implied only from the product (Nevo, 1997; VanTassel-Baska, 2001). Thus, the most useful tool left for the study of creativity is the product. The creative productwhether it be an actual, physical object or an expressed idea-is the proof or evidence that creativity has occurred (Kleiman 2005). Because of its tangibility, it is probably the easiest element for the assessment of creativity.

\section{Assessing the Quality of Creative Thinking via the Assessment of Creative Products}

The assessment of creative processes can be deduced from the features of the creative products. Some of these well-agreed 
upon features are: originality (or newness), appropriateness, elaborateness and flexibility (e.g. Amabile, 1996; Klavir \& Hershkovitz, 2008; Nevo, 1997; Runco, 2005; Sternberg \& Lubart, 1999): Originality - expresses the deviation of the product from routine solutions, i.e. being different, unique, unexpected and/or non-conventional. Appropriateness-reflects the attendance of the individual to cope with the constraints of the task of creativity. Elaborateness-relates to the degree the new product is upgraded in comparison to the already known. The more the product includes new structural relations the more it is considered to be on a higher thinking level. Flexibility - relates to the context and the content of the new product. The more the context and content of the new product are far removed from the source problem it reflects a higher flexibility of the individual to shift to new areas, i.e. a further transfer.

It's important to emphasize that each one of these dimensions illuminates creative thinking from a different perspective (Bonk, 2003; Guilford, 1967; Klavir \& Gorodetsky, 2009; Klavir \& Hershkovitz, 2008) and thus, using only one of these dimensions is not sufficient for deducing neither the creative qualities of the product nor the quality of the creative thinking process (Briskman, 1980; Besemer \& O’Quin, 1993).

\section{The Readiness to Construct New Products as a Means to Assess the “Creative Person” (Motivation)}

Information regarding the person's readiness (i.e. motivation) to get involved in a creative process is simply manifested by the production of a product (e.g. Feldman, 1999; Sternberg \& Lubart, 1996). This readiness is one of the essential features of creative people (e.g. Kleiman, 2005; Nevo, 1997; Van-tassel Baska, 2001; Sternberg \& Lubart, 1996). For some the mere engagement in a creative process itself is satisfying whereas others are in need of the community's approval as to their creativeness (Feldman, 1999). According to Runco (2005), motivation can influence the thinking processes and lead to the production of multiple products that in turn re-influence the thinking processes. Meaning, the person's appraisal regarding his capability to cope with the task, becomes a source for enhanced motivation to get involved in further producing original and new products. Furthermore, people's negative appraisal of their capabilities to cope with the task such as lack of required knowledge, skills or abilities, results in avoiding creative processes (El-Murad \& West, 2004). Thus, for the study of creativity the choice of an appropriate context and a suitable task that ensures the manifestation of creative features, is essential.

\section{Features Regarding Appropriate Tasks for the Study of Creativity}

The selection of a task for the assessment of creativity is of utmost importance. Different kinds of tasks yield different levels of creativity (Mumford et al., 2002). Therefore, the task has to encapsulate possibilities for activating and expressing creative modes of thinking. Furthermore, it is advised to use more than one kind of task in a certain study. The research literature suggests some well-agreed features regarding appropriate tasks for the study of creativity. These include the following features:

1) "Open-ended" tasks including complex, ill-defined problems that are difficult to be solved and for which conventional responses do not work (Amabile, 1996: p. 41; Mumford, et al.,
2002: p. 707).

2) Tasks that demand previous knowledge. Creativity was found to depend on specific knowledge in the field of the tasks (e.g. Runco, 2005; Kleiman, 2005). Thus, the problems have to be adjusted to the knowledge of the persons performing the creative processes (Amabile, 1996; Hennessey \& Amabile, 1988; Reiter-Palmon, Mumford, O’Connor, \& Runco, 1997). According to Mumford et al. (2002) the person's knowledge is important since it enables him to redefine the task at hand, to gather further information for its deep understanding, to combine and reorganize the information in new conceptual combinations and to use analogical reasoning to construct new representations towards generating creative ideas.

3) Tasks that involve analogical thinking have the potential to shed light on the processes involved in the production of creative ideas (Martindale, 1999). Gentner et al., (1997) suggest that the construction of new analogical ideas depends on high cognitive abilities i.e. the ability to draw abstract structural similarities between analogical problems. Thus the more the new analogical situations are far removed from the source problem the more they reflect higher cognitive abilities (Runco, 2007: pp. 12-14) and more creative thinking (Shye \& Goldzweig, 1999). Following this knowledge the construction of analogical problems seems to be a suitable task for the study of creativity especially as this process is associated with cognitive flexibility and elaboration (Bull, Montgomery, \& Kimball, 1999).

The present research attempted to assess the nature of creativity of intellectually gifted students vs. "regular" one, on two dimensions: 1) assessing their readiness to get involved in the construction of new product; and 2) assessing the creative qualities expressed in the constructed products. The research hypothesis was that the gifted students as compared to the "regulars" will exhibit a higher readiness to get involved in the construction of new products (analogical problems) and that their constructed problems will be found to be more creative based on criteria for creativity described above. Runco (2005) found that intellectually gifted children are often appearing to be "on fire" and strongly engaged in their domains of interest. Similarly, Winner (1997) found that gifted children derive pleasure from coping with challenges. This intrinsic motivation is explained by Winner (2000) and Hennessey (2004) as arising from their feelings of competence that are nourished from their past successes in coping with creative tasks. Gifted students were also found to be characterized by cognitive capabilities that affect their mode of thinking and lead to creative productions. These capabilities include generative thinking (e.g., Ward et al. 1999), analogical complex thinking and insight capabilities (Davidson, 1986; Klavir \& Gorodetsky, 2001), flexible abilities (e.g. Dover \& Shore, 1991), high order reasoning as well as convergent and divergent thinking (Rex, 1996).

\section{Method}

\section{The Subjects}

Two groups of students were chosen for this task.

The gifted students were seventh and eighth graders with an IQ defined by the Ministry of Education as being above of 135 $(\mathrm{N}=232)$. They studied in regular high-schools however they 
were part of an enrichment program catered specifically for gifted.

The "regular" students were eighth and ninth graders defined as neither gifted nor as special education students $(\mathrm{N}=229)$ that studied in regular classes and were from a similar urban, middle-class background, and went to the same comprehensive junior high-schools. The difference in the ages of the populations was to ensure a similar mental age (Planche, 1985).

\section{The Task}

The students in both groups were asked to solve only one problem that was either a mathematical multistage problem, an insight-mathematical problem, or an insight-non-mathematical (verbal) problem (see appendix 1). Thus the research relates to three kinds of problems that were solved by the involved students:

The mathematical problem: this problem was taken from a group of challenging problems in a mathematics textbook for the $8^{\text {th }}$ grade. It was chosen in cooperation with six mathematics teachers of the $7^{\text {th }}-9^{\text {th }}$ heterogeneous classes. The problems were evaluated by the teachers as being more complex than the average classroom problems but yet being based on the schoollearned mathematical knowledge.

The mathematical and verbal insight problems: insight problems that "requires restructuring of a problem space by stepping out of the framework provided by the commonly activated cognitive schemas and acquiring a new perspective on the problem" (Karimi, Windman, Güntürkün, \& Abraham, 2007). One of these problems necessitated mathematical knowledge (insight-mathematical problem) while the other was based on common knowledge (insight-non-mathematical (verbal) problem). The problems were compiled from a number of puzzle books (e.g., Lake, 1976) and shared similar attributes, as described by Davidson (Davidson, 1986; Davidson \& Sternberg, 1984). According to Davidson, the solution of such problems involves the restructuring of the problem space that is based on three selective cognitive processes: selective encoding, selective combination, and selective comparison. The choice of the specific problems for the study was based on an independent study in which students were asked to solve five chosen problems in these categories. The chosen problems for the study were in the upper quartile (the 75th percentile) of difficulty.

\section{The Design}

The design included three phases: in the first phase students received a questionnaire in which they were asked to solve one problem (source problem). In the second phase, the students received two solved problems for learning: one problem was analogous to the source one and the other was a distracting problem with a similar surface structure but with a different deep structure. Students were asked to study the solution processes and then to recite the problems and their solutions in their own words. This design follows previous researches as a means to ensure the participants' engagement in the learning process (Reiter-Palmon et al., 1997). The third phase was undertaken two weeks later. At this phase the students were asked to solve again the source problem and to construct a new analogous problem of their own that is as far removed from the source one as possible. Students that didn't complete the second phase seriously, meaning there was no indication for a learning proc- ess of the analogous and the distracting problems, were excluded from the analysis. Following Mumford (1998), this was to ensure that all subjects have learned to solve the problems, i.e. have the appropriate knowledge.

\section{Data Analysis}

\section{The Defined Variables}

1) Readiness to construct a creative product - relates to students' motivation to construct new analogous problems. The assessment is based on the number of students that constructed a new analogous problem regardless its quality. All students that accomplished the three phases were divided into two groups: those that did construct a new problem and those that didn't. The group of students that constructed a new problem was defined as that which expressed readiness to construct a creative product, whereas the other group was defined as the non-motivated one.

2) The creative quality of the new products-was assessed on the basis of the criteria as suggested above: a) Flexibility: This criterion relates to the extent of similarity between the surface structures (content and context) of the constructed problem to that of the source one. The more the surface structure of the constructed problem was removed from the source one it was considered to be more flexible. Three levels of flexibility were defined: completely different, when the content and context of the story in the constructed problem were completely different from those in the source problem; similar, when the content of the story in the constructed problem was different but its context was similar to that in the source problem; and identical, when the content and context of the story in the constructed problem were identical to those in the source problem. b \& c) Appropriateness \& Elaborateness: This variable expressed the extent of similarity in the solution structures between the new constructed problem and the source one: The further the structural elements or relations (logical or mathematical) in the constructed problem were removed from those in the source problem, the constructed problem was considered to be more creative (for a similar method, see Bassok et al., 1998). Since elaboration can be examined only for appropriate (relevant) problems, these two measures of appropriateness and elaborateness were combined and appear as a joint variable. Three levels were assigned for the combined variable: different was assigned when the solution structure of the constructed problem was appropriate (relevant) and elaborated; identical was assigned to constructed problems that their solution structure was appropriate but was not elaborated; and inappropriate for cases in which the constructed problems included solution structures that were irrelevant to the source problem. d) Originality: This variable expresses the extent to which the constructed problems were very original, partially original or not original. The assessment was based on a subjective judgment following Amabile's (1996) instructions: 1) External judges were asked to grade the originality of the constructed problems using their subjective judgment without pre-defined criteria. 2) Then the judges were asked to rate the levels of originality of each problem relatively to the other constructed ones. e) The cumulative creativity measure was assigned on the basis of the above criteria: high cumulative creativity was assigned to products that included the most creative features as defined above, i.e. high cumulative creativity was assigned to con- 
structed problems that were assessed as the most flexible, appropriate, elaborated and original. Lower cumulative creativity was assigned to the rest of the constructed problems. For analyzed examples, see Appendix 2.

\section{The Process of Analysis}

The analysis of the constructed problems was performed by 10 paid graduate students. The assessing students were trained in a similar manner as described by Reiter-Palmon et al. (1997). The training session started with all students attending to a similar questionnaire and attempting to assess the variables listed above. Then, each of them assessed a questionnaire on her/his own. After this assessment the students were brought together to compare their assessments and discuss possible discrepancies. In the next stage each couple received the same 10 questionnaires for assessment. Then all pairs met for comparison of the discrepancies in their ratings. After this training, they continued the assessment process in couples. Each couple analyzed all 461 questionnaires separately. The final assigned values for the constructed problems were those assigned by the majority of couples and not on the basis of an average as suggested by others (e.g. that of Reiter-Palmon et al., 1997 or Hennessey \& Amabile, 1988).

\section{Results}

\section{The Connection between "the Readiness to Create a New Product” and Creativity}

It was found that more gifted students were ready to construct new analogical problems for all three kinds of problems (Table 1): for the insight-mathematical problem-out of the number of those who did construct new analogical problems ( $45 \%$ out of the students), $61 \%$ were gifted vs. $39 \%$ that were "regulars", $\left[\mathrm{X}^{2}(1, \mathrm{~N}=155)=9.58 p<.01\right]$; for the mathematical problem-out of the number of those who did construct new analogical problems (54\% out of the students), 75\% were gifted vs. $25 \%$ that were "regulars", $\left[\mathrm{X}^{2}(1, \mathrm{~N}=149)=35.40 \mathrm{p}\right.$ $=.001]$; for the insight-verbal problem - out of the number of those who did construct new analogical problems (31\% out of the students), $78 \%$ were gifted vs. $22 \%$ that were "regulars", $\left[\mathrm{X}^{2}(1, \mathrm{~N}=157)=21.13 p=.001\right]$.

The results verify that indeed intellectually gifted students are more prone to construct new analogical problems, i.e. are more motivated to construct new creative products than the "regulars". This difference is valid for all products (in our case: insightmathematical, mathematical and insight-verbal problems).

\section{The Connection between Intellectual Giftedness and Creativity as Manifested in the Constructed Problems}

Five $\mathrm{X}^{2}$ tests were conducted for the five criteria expressing dimensions of creative quality of the constructed analogical problems:

1) Flexibility (Table 2): the insight-mathematical problem 25 out of the 43 (58\%) gifted students as compared to 8 out of the 27 (30\%) "regular" students constructed a different problem $\left[\mathrm{X}^{2}(2, \mathrm{~N}=70)=5.65 p=.06^{*}\right]$ (*with enlarging the Alfa rate); the mathematical problem-there was no difference between the gifted students (62\%) and the "regulars" (55\%); the insight problem-19 out of the 38 (50\%) gifted students as compared to 2 out of the 11 (30\%) "regular" students constructed a different problem $\left[\mathrm{X}^{2}(2, \mathrm{~N}=49)=7.70 p<.05\right]$.

2 \& 3) Appropriateness \& Elaborateness (Table 3): the insight-mathematical problem-20 out of the $40(47 \%)$ gifted students as compared to 21 out of the 27 (78\%) "regular" students constructed an inappropriate problem, whereas 10 out of the $43(23 \%)$ gifted students as compared to only 1 out of the 27 (4\%) "regular" students constructed a new problem that was appropriate and also elaborated $\left[\mathrm{X}^{2}(2, \mathrm{~N}=70)=7.69 p<.05\right]$; the mathematical problem - there was no difference between the gifted students and the "regulars" as measured on appropriateness and elaborateness of the constructed problems. Only 7 out of the 61 gifted students (12\%) and 3 out of the 20 (15\%) "regular" students constructed a problem that was appropriate and also elaborated; the insight problem-14 out of the 38 (37\%) gifted students as compared to 7 out of the 11 (64\%) "regular" students constructed an inappropriate problem, whereas 10 out of the 38 (26\%) gifted students as compared to 0 out of the $11(0 \%)$ "regular" students constructed a problem that was appropriate and also elaborated $\left[\mathrm{X}^{2}(2, \mathrm{~N}=49)=6.39 p\right.$ $<$.05].

4) Originality (Table 4): the insight-mathematical problem -17 out of the $43(61 \%)$ gifted students as compared to 1 out of the 27 (4\%) "regular" students constructed a "very original" problem $\left[\mathrm{X}^{2}(2, \mathrm{~N}=70)=13.85 p<.05\right]$; the mathematical

Table 1.

The readiness to construct a new product: the number of students (gifted/“regulars” and beyond) that constructed new problems.

\begin{tabular}{|c|c|c|c|c|c|c|c|c|c|}
\hline & \multicolumn{9}{|c|}{ The kind of the problem } \\
\hline & \multicolumn{3}{|c|}{$\mathrm{I}-\mathrm{M}^{1}$} & \multicolumn{3}{|c|}{ M } & \multicolumn{3}{|c|}{$\mathrm{I}-\mathrm{V}$} \\
\hline & $G^{2}$ & “ $R ”$ & $T$ & G & “R” & $T$ & G & “R” & $T$ \\
\hline \multirow{3}{*}{ Did construct an analogous problem } & 43 & 27 & 70 & 61 & 20 & 81 & 38 & 11 & 49 \\
\hline & $61 \%^{\mathrm{a}}$ & $39 \%$ & $100 \%$ & $75 \%$ & $25 \%$ & $100 \%$ & $78 \%$ & $22 \%$ & $100 \%$ \\
\hline & $58 \%{ }^{\mathrm{b}}$ & $33 \%$ & $45 \%$ & $77 \%$ & $29 \%$ & $54 \%$ & $48 \%$ & $14 \%$ & $31 \%$ \\
\hline \multirow{3}{*}{ Did not construct an analogous problem } & 31 & 54 & 85 & 18 & 50 & 68 & 41 & 67 & 108 \\
\hline & $37 \%$ & $63 \%$ & $100 \%$ & $27 \%$ & $73 \%$ & $100 \%$ & $38 \%$ & $62 \%$ & $100 \%$ \\
\hline & $42 \%$ & $67 \%$ & $55 \%$ & $23 \%$ & $71 \%$ & $46 \%$ & $52 \%$ & $86 \%$ & $69 \%$ \\
\hline \multirow{3}{*}{ Total } & 74 & 81 & 155 & 79 & 70 & 149 & 79 & 78 & 157 \\
\hline & $48 \%$ & $52 \%$ & $100 \%$ & $53 \%$ & $47 \%$ & $100 \%$ & $50 \%$ & $50 \%$ & $100 \%$ \\
\hline & $100 \%$ & $100 \%$ & $100 \%$ & $100 \%$ & $100 \%$ & $100 \%$ & $100 \%$ & $100 \%$ & $100 \%$ \\
\hline
\end{tabular}

1. I-M: The insight- mathematical problem; M: The mathematical problem; I-V: The insight- verbal problem. 2. G: gifted students; "R": "regular" students; T: Total (beyond). a. Within raw; b. Within column. 
Table 2.

The flexibility levels of the constructed problems by gifted and "regulars".

\begin{tabular}{|c|c|c|c|c|c|c|c|c|c|}
\hline Different & $\begin{array}{c}25 \\
76 \% \\
58 \%\end{array}$ & $\begin{array}{c}8 \\
24 \% \\
29 \%\end{array}$ & $\begin{array}{c}33 \\
100 \% \\
47 \%\end{array}$ & $\begin{array}{c}38 \\
78 \% \\
62 \%\end{array}$ & $\begin{array}{c}11 \\
22 \% \\
55 \%\end{array}$ & $\begin{array}{c}49 \\
100 \% \\
61 \%\end{array}$ & $\begin{array}{c}19 \\
91 \% \\
50 \%\end{array}$ & $\begin{array}{c}2 \\
9 \% \\
18 \%\end{array}$ & $\begin{array}{c}21 \\
100 \% \\
43 \%\end{array}$ \\
\hline Similar & $\begin{array}{c}15 \\
50 \% \\
35 \%\end{array}$ & $\begin{array}{c}15 \\
50 \% \\
56 \%\end{array}$ & $\begin{array}{c}30 \\
100 \% \\
43 \%\end{array}$ & $\begin{array}{c}13 \\
72 \% \\
21 \%\end{array}$ & $\begin{array}{c}5 \\
28 \% \\
25 \%\end{array}$ & $\begin{array}{c}18 \\
100 \% \\
22 \%\end{array}$ & $\begin{array}{c}15 \\
79 \% \\
40 \%\end{array}$ & $\begin{array}{c}4 \\
21 \% \\
36 \%\end{array}$ & $\begin{array}{c}19 \\
100 \% \\
39 \%\end{array}$ \\
\hline Identical & $\begin{array}{c}3 \\
43 \% \\
7 \%\end{array}$ & $\begin{array}{c}4 \\
57 \% \\
15 \%\end{array}$ & $\begin{array}{c}7 \\
100 \% \\
10 \%\end{array}$ & $\begin{array}{c}10 \\
71 \% \\
16 \%\end{array}$ & $\begin{array}{c}4 \\
29 \% \\
20 \%\end{array}$ & $\begin{array}{c}14 \\
100 \% \\
17 \%\end{array}$ & $\begin{array}{c}4 \\
44 \% \\
10 \%\end{array}$ & $\begin{array}{c}5 \\
56 \% \\
46 \%\end{array}$ & $\begin{array}{c}9 \\
100 \% \\
18 \%\end{array}$ \\
\hline Total & $\begin{array}{c}43 \\
61 \% \\
100 \%\end{array}$ & $\begin{array}{c}27 \\
39 \% \\
100 \%\end{array}$ & $\begin{array}{c}70 \\
100 \% \\
100 \%\end{array}$ & $\begin{array}{c}61 \\
75 \% \\
100 \%\end{array}$ & $\begin{array}{c}20 \\
25 \% \\
100 \%\end{array}$ & $\begin{array}{c}81 \\
100 \% \\
100 \%\end{array}$ & $\begin{array}{c}38 \\
78 \% \\
100 \%\end{array}$ & $\begin{array}{c}11 \\
22 \% \\
100 \%\end{array}$ & $\begin{array}{c}49 \\
100 \% \\
100 \%\end{array}$ \\
\hline
\end{tabular}

Table 3.

Appropriateness \& Elaborateness levels of problems that were constructed by gifted and "regulars".

\begin{tabular}{|c|c|c|c|c|c|c|c|c|c|}
\hline Different & $\begin{array}{c}10 \\
91 \% \\
23 \%\end{array}$ & $\begin{array}{c}1 \\
9 \% \\
4 \%\end{array}$ & $\begin{array}{c}11 \\
100 \% \\
16 \%\end{array}$ & $\begin{array}{c}7 \\
70 \% \\
12 \%\end{array}$ & $\begin{array}{c}3 \\
30 \% \\
15 \%\end{array}$ & $\begin{array}{c}10 \\
100 \% \\
12 \%\end{array}$ & $\begin{array}{c}10 \\
100 \% \\
26 \%\end{array}$ & $\begin{array}{c}0 \\
0 \% \\
0 \%\end{array}$ & $\begin{array}{c}10 \\
100 \% \\
20 \%\end{array}$ \\
\hline Identical & $\begin{array}{c}13 \\
72 \% \\
30 \%\end{array}$ & $\begin{array}{c}5 \\
28 \% \\
18 \%\end{array}$ & $\begin{array}{c}18 \\
100 \% \\
26 \%\end{array}$ & $\begin{array}{c}24 \\
86 \% \\
39 \%\end{array}$ & $\begin{array}{c}4 \\
14 \% \\
20 \%\end{array}$ & $\begin{array}{c}28 \\
100 \% \\
35 \%\end{array}$ & $\begin{array}{c}14 \\
78 \% \\
37 \%\end{array}$ & $\begin{array}{c}4 \\
22 \% \\
36 \%\end{array}$ & $\begin{array}{c}18 \\
100 \% \\
37 \%\end{array}$ \\
\hline Irrelevant & $\begin{array}{c}20 \\
49 \% \\
47 \%\end{array}$ & $\begin{array}{c}21 \\
51 \% \\
78 \%\end{array}$ & $\begin{array}{c}41 \\
100 \% \\
58 \%\end{array}$ & $\begin{array}{c}30 \\
70 \% \\
49 \%\end{array}$ & $\begin{array}{c}13 \\
30 \% \\
65 \%\end{array}$ & $\begin{array}{c}43 \\
100 \% \\
53 \%\end{array}$ & $\begin{array}{c}14 \\
67 \% \\
37 \%\end{array}$ & $\begin{array}{c}7 \\
33 \% \\
64 \%\end{array}$ & $\begin{array}{c}21 \\
100 \% \\
43 \%\end{array}$ \\
\hline Total & $\begin{array}{c}43 \\
61 \% \\
100 \%\end{array}$ & $\begin{array}{c}27 \\
39 \% \\
100 \%\end{array}$ & $\begin{array}{c}70 \\
100 \% \\
100 \%\end{array}$ & $\begin{array}{c}61 \\
75 \% \\
100 \%\end{array}$ & $\begin{array}{c}20 \\
25 \% \\
100 \%\end{array}$ & $\begin{array}{c}81 \\
100 \% \\
100 \%\end{array}$ & $\begin{array}{c}38 \\
78 \% \\
100 \%\end{array}$ & $\begin{array}{c}11 \\
22 \% \\
100 \%\end{array}$ & $\begin{array}{c}49 \\
100 \% \\
100 \%\end{array}$ \\
\hline
\end{tabular}

problem - there was no difference between the gifted students (31\%) and the "regulars" (25\%); the insight problem-18 out of the 38 (47\%) gifted students as compared to 4 out of the 11 (36\%) "regular" students, constructed a "very original” problem $\left[\mathrm{X}^{2}(1, \mathrm{~N}=70)=5.67 p<.05\right]$.

5) The cumulative creativity measure (Table 5): the insight-mathematical problem-8 out of the 43 (19\%) gifted students as compared to 0 out of the 27 (4\%) "regular" students were found as more creative according to this criterion $\left[X^{2}(1, N\right.$ $=70)=5.67 p<.05$ ]; the mathematical problem - there was no difference between the gifted students $(11 \%)$ and the "regulars" (15\%); the insight problem-8 out of the 38 (21\%) gifted students as compared to 0 out of the $11(0 \%)$ "regular" students were found as more creative on this criterion $\left[X^{2}(1, N=49)=\right.$ $2.77 p=.09^{*}$ ( $*$ with enlarging the Alfa rate).

On the basis of the five creativity features of the constructed problems, i.e. the creative products, the intellectually gifted students were found to be more creative than the "regulars" on the insight problem. The constructed insight analogical problems (verbal as well as mathematical) of the gifted students were more flexible, more appropriate, more elaborate, and original and had a higher level of cumulative creativity. As to the constructed mathematical analogical problems these differences between the gifted and "regulars" were not found.

\section{The Connection between Intellectually Gifted and Creativity beyond the Specific Nature of Problems}

For this analysis, the results obtained for the three problems were combined. It was found that:
Readiness (motivation to create) (Figure 1): out of the 461 students that participated in the task (232 gifted students and 229 "regulars”) 200 (43\%) students exhibited readiness to construct a problem: $71 \%$ out of them were gifted and $29 \%$ were "regulars", $\left[X^{2}(1, N=461)=60.40 p<.001\right]$. These included $61 \%$ of the gifted and $25 \%$ out of the "regulars".

The creative quality of the constructed problems (products) (Figure 2): a) Flexibility: 58\% ( 82 out of the 142) gifted students as compared to $36 \%$ (21 out of the 58) students constructed flexible (different) problems $\left[\mathrm{X}^{2}(2, \mathrm{~N}=200)=8.22\right.$ $p<.05$ ]. $\mathrm{b}+\mathrm{c}$ ) Appropriateness \& Elaborateness: 19\% (27 out of the gifted students ) as compared to $7 \%$ (4 out of the "regular" students) constructed new problems that were both appropriate and elaborated $\left[\mathrm{X}^{2}(2, \mathrm{~N}=200)=11.40 p<.05\right]$. d) Originality: $38 \%$ (54 out of the 142) gifted students as compared to $17 \%$ (10 out of the 58) "regular" students were found to be more original according to this criterion $\left[X^{2}(2, N=200)\right.$ $=15.87 p<.001]$. e) The cumulative creativity measure: $16 \%$ (23 out of the 142) gifted students as compared to 5\% (3 out of the 58) "regular" students were assessed as having a high cumulative creativity $\left[\mathrm{X}^{2}(1, \mathrm{~N}=200)=4.43 p<.05\right]$.

These results verified that the intellectually gifted students as compared to the "regular" ones, did exhibit higher levels of creativity.

\section{Discussion}

The paper attempted to answer the question as to the connection between giftedness and creativity by analyzing students' 
Table 4.

The originality levels of problems that were constructed by gifted and "regulars".

\begin{tabular}{|c|c|c|c|c|c|c|c|c|c|}
\hline \multirow{3}{*}{ Very original } & 17 & 1 & 18 & 19 & 5 & 24 & 18 & 4 & 22 \\
\hline & $94 \%$ & $6 \%$ & $100 \%$ & $79 \%$ & $21 \%$ & $100 \%$ & $82 \%$ & $18 \%$ & $100 \%$ \\
\hline & $40 \%$ & $4 \%$ & $26 \%$ & $31 \%$ & $25 \%$ & $30 \%$ & $47 \%$ & $36 \%$ & $45 \%$ \\
\hline \multirow{3}{*}{ Partially original } & 22 & 17 & 39 & 30 & 8 & 38 & 15 & 1 & 16 \\
\hline & $56 \%$ & $44 \%$ & $100 \%$ & $79 \%$ & $21 \%$ & $100 \%$ & $94 \%$ & $6 \%$ & $100 \%$ \\
\hline & $51 \%$ & $63 \%$ & $56 \%$ & $49 \%$ & $40 \%$ & $47 \%$ & $40 \%$ & $9 \%$ & $33 \%$ \\
\hline \multirow{3}{*}{ Non original } & 4 & 9 & 13 & 12 & 7 & 19 & 5 & 6 & 11 \\
\hline & $31 \%$ & $69 \%$ & $100 \%$ & $63 \%$ & $37 \%$ & $100 \%$ & $45 \%$ & $55 \%$ & $100 \%$ \\
\hline & $9 \%$ & $33 \%$ & $19 \%$ & $20 \%$ & $35 \%$ & $23 \%$ & $13 \%$ & $55 \%$ & $22 \%$ \\
\hline \multirow{3}{*}{ Total } & 43 & 27 & 70 & 61 & 20 & 81 & 38 & 11 & 49 \\
\hline & $61 \%$ & $39 \%$ & $100 \%$ & $75 \%$ & $25 \%$ & $100 \%$ & $78 \%$ & $22 \%$ & $100 \%$ \\
\hline & $100 \%$ & $100 \%$ & $100 \%$ & $100 \%$ & $100 \%$ & $100 \%$ & $100 \%$ & $100 \%$ & $100 \%$ \\
\hline
\end{tabular}

Table 5.

The cumulative measure: the number of the most creative analogical problems that were constructed by gifted and "regulars".

\begin{tabular}{cccccccccc}
\hline & 8 & 0 & 8 & 7 & 3 & 10 & 8 & 0 & 8 \\
A higher cumulative & $100 \%$ & $0 \%$ & $100 \%$ & $70 \%$ & $15 \%$ & $100 \%$ & $100 \%$ & $0 \%$ & $100 \%$ \\
creativity quality & $19 \%$ & $0 \%$ & $11 \%$ & $12 \%$ & $30 \%$ & $12 \%$ & $21 \%$ & $0 \%$ & $16 \%$ \\
& 35 & 27 & 62 & 54 & 17 & 71 & 30 & 11 & 41 \\
A lower cumulative & $57 \%$ & $43 \%$ & $100 \%$ & $76 \%$ & $24 \%$ & $100 \%$ & $94 \%$ & $27 \%$ & $100 \%$ \\
creativity quality & $81 \%$ & $100 \%$ & $89 \%$ & $88 \%$ & $85 \%$ & $88 \%$ & $40 \%$ & $100 \%$ & $84 \%$ \\
& 43 & 27 & 70 & 61 & 20 & 81 & 38 & 11 & 49 \\
Total & $61 \%$ & $39 \%$ & $100 \%$ & $75 \%$ & $25 \%$ & $100 \%$ & $78 \%$ & $22 \%$ & $100 \%$ \\
& $100 \%$ & $100 \%$ & $100 \%$ & $100 \%$ & $100 \%$ & $100 \%$ & $100 \%$ & $100 \%$ & $100 \%$ \\
\hline
\end{tabular}

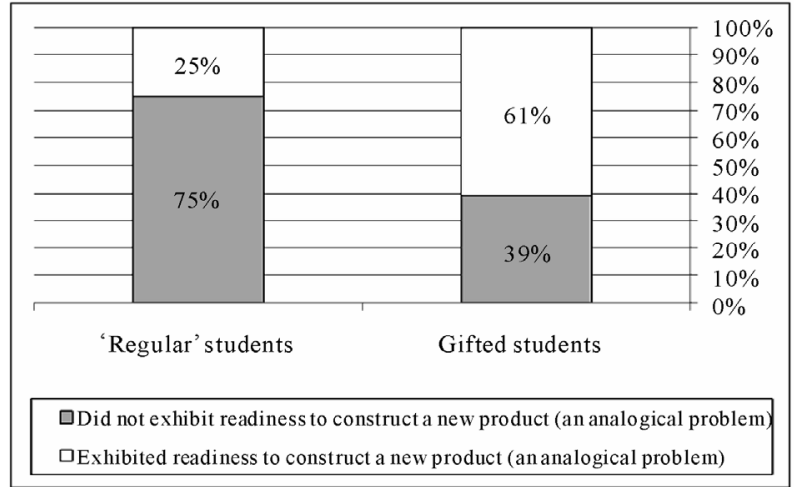

Figure 1.

The percentages of students (gifted vs. "regular") that exhibited/didn't exhibit readiness (motivation) to construct an analogical problem.

readiness to construct analogical problems and by assessing the creative features of these. We have followed some recommendations such as adjusting the context to our students and the goal of the study. Thus we chose three kinds of problems: insight-mathematical, mathematical and insight-verbal, that on the one hand have the potential to activate creativity and that their knowledge-base and complexity matches the high-order thinking of gifted students. Furthermore, using three kinds of problems enabled us to expose creative behavior on a few dimensions. All subjects, gifted as well as the "regulars", learned the problems and only than were asked to construct an analogical problem. Thus we verified that the subjects had the appropriate knowledge to cope with the construction of analogous problems. Students' readiness to get involved in this process and the creative nature of these products were assessed.

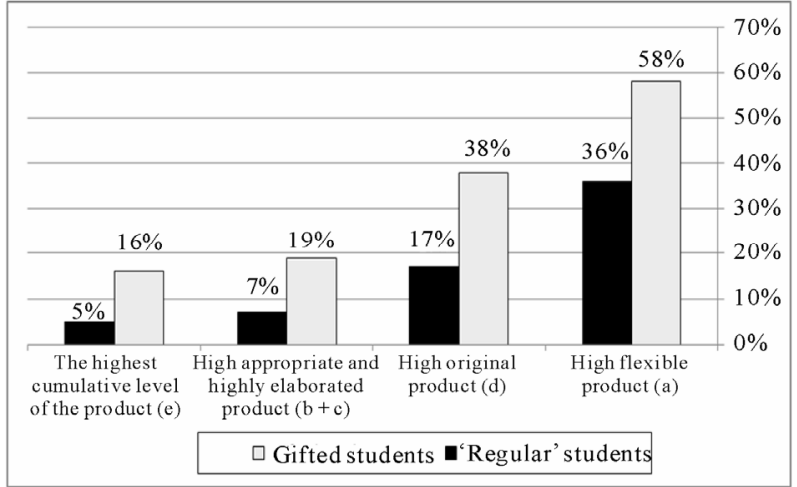

Figure 2.

The percentages of students (gifted vs. "regular") that exhibited high creative qualities in their constructed analogical problem.

We believe that the more comprehensive methodology that attended to different aspects of creativity supports the connection between intellectual giftedness and creativity.

\section{The Connection between Intellectual Giftedness and Creativity—a General Perspective}

It was found that creativity as a general feature characterizes more the intellectually gifted students than the 'regulars'. This was reflected in their higher readiness than the 'regulars' to as shown in Figure 1 and in their high level of creativity features (flexibility, appropriateness \& elaborateness, originality and the cumulative creative quality) in their products (Figure 2).

These results give further empirical support to the claim that the quality of the product can reflect high order thinking 
(Briskman, 1980; Besemer \& O’Quin, 1993; Klavir \& Hershkovitz, 2008; Kleiman, 2005) and that the high order thinking of gifted students is connected to high creative ability (Klavir \& Gorodetsky, 2009; Shye \& Goldzweig 1999). Furthermore, the present results give empirical support to the claim that the excellence of gifted students is reflected not only in their cognitive ability (as it is measured by IQ tests) but also in their higher readiness/ motivation to be involved in complex missions and in their higher creative ability to refine and produce new products with high creative qualities. These results are in coherence with the three-ring theory of Renzulli (1998) who claims that behavior of the gifted is a combination of three characteristics (rings): high general ability (intelligence), high task commitment and high creativity.

Furthermore, the high readiness (motivation) of the gifted students to get involved in the construction of analogical problems is in agreement with the claims in the literature as to the features of populations that express readiness to get involved in creative processes. Schunk \& Pajares (2005) claim that "Individuals select tasks and activities in which they feel competent and avoid those in which they do not. Unless people believe that their actions will have the desired consequences, they have little incentive to engage in those actions" (p. 87).

\section{The Connection between Intellectual Giftedness and Creativity -in Contextual Point of View}

A more detailed analysis indicated that the creativity of the gifted students was context dependent. The constructed analogical "insight" problems (the mathematical as well as the verbal) were more flexible, more appropriate and elaborated and more original (Tables 2-4) than those of the "regulars". Moreover, $19 \%$ of the gifted students were found to construct problems with a high cumulative creativity level in the insightmathematical problems and $21 \%$ in the insight-verbal problems, whereas none of the "regular" student achieved such products (Table 5). As to the constructed analogical mathematical problem no significant differences were found between both groups that exhibited similar levels of creativity.

These results are congruent with the findings in the research literature regarding the unique qualities of intellectually gifted students as being competent in high-order logical and insightful thinking. It is possible that for the gifted students the mathematical, class-room like problem, was not perceived as a real challenge. They did show a higher motivation than the "regulars", to construct an analogical problem but their predisposition towards the task was as towards a routine, conventional, familiar and unchallenging assignment. In another study (Gorodetsky \& Klavir, 2003; Klavir \& Gorodetsky, 2001) we have provided gifted student with cartoons and analogical verbal problems for solution. We have found that the cartoons were more difficult for the gifted than the verbal problems. It was only after the gifted realized that the cartoons are a kind of problem and their predisposition towards the cartoons changed, that their level of success increased.

Of course, it is also possible that the similar performance on the mathematical problem of the gifted and the "regulars" stems not from a decrease of that of the gifted but rather from a relative increase of that of the "regulars". The increase in the "regulars" creativity may stem from their familiarity with such classroom encounters. The source problems and the worked out analogous one were similar to other school mathematical problems that both groups probably came across in their studies. Moreover, along their structured learning in school they probably learned to identify analogical problems, to map their relevant analogical features (surface and deep structure components) and the possibilities for transfer to new situations. This attunement to the nature of analogical problems probably aided the "regulars" in the construction of creative mathematical problems. These findings support the research results by Gentner et al. (2003: p. 402) that the construction of schemes of the solution of analogical problems support transfer to new target problems.

Another possibility is that students' dispositions towards the mathematical familiar school problems was in favor of the "regulars" in learning the worked out problems they have been provided with. The acquired knowledge strengthened their motivation to get involved in the production of analogous products.

\section{The Connection between Intellectual Giftedness and Creativity-a Comparison from a Relative Point of View}

The creativity of the gifted students' can be addressed from a different point of view, not as compared to "regulars" but relatively to themselves, i.e. as compared to the optimum that could be achieved. Though a high percentage of gifted students expressed a higher motivation to get involved in the creative process (in comparison to the "regulars") and although the features of creativity expressed in the constructed problem were higher than those of the "regulars", in fact their creativity was not high. From the 232 gifted students in the initial group, only 142 students $(61 \%)$ were ready to be involved in the creative activity (graph no. 1). Furthermore, from this group (142 gifted students) only 23 (16\%) students constructed new problems of a high cumulative creativity nature. As to their performance on the specific creativity features only $58 \%$ of their products were highly flexible, $38 \%$ were very original and $19 \%$ were appropriate and also highly elaborated (Figure 2). Thus, though the gifted expressed a higher creativity as compared to the "regulars") their relative creativity seems to be quite disappointing.

The results encouraged us to attend to two different measures of creativity: Comparative Creativity and Relative Creativity. Comparative Creativity measures the creativity level of gifted students in comparison to their "regular" peers, i.e. to what extent are their products more flexible, appropriate \& elaborated and original. The results indeed indicate that on these measures the intellectually gifted students are more creative than "regular" students. Relative Creativity refers to the creativity level of the gifted students in comparison to the optimum of themselves. Form this point of view the gifted students did not perform on a high level. They did not exhibit a high motivation to construct new problems not were the features of creativity of the constructed problem on an as optimal level.

Such a differentiation between two measures of creativity, comparative and relative, may be the reason for some inconsistencies in the research literature.

From the educational point of view, these results strongly support the need for further educational investment in the gifted students. It seems that for the development of creativity additional educational investments are in need. Baer \& Kaufman 
(2005) express such a need: "Finding the right conceptualization of creativity matters in gifted education because developing students' potential as creative thinkers is (or should be) one of the most important goals of education" (p. 162). Thus progressive nurturing of gifted students is not only needed for "occupational" needs in the class-room, but it is essential for their development as creative students. Education must make efforts to nurture the creative abilities of gifted students towards their fulfillment.

\section{References}

Amabile, T. M. (1996). Creativity in context. Boulder, CO: Westview Press.

Baer, J., \& Kaufman, J. C. (2005). Bridging generality and specificity: The Amusement Park Theoretical (APT) model of creativity. Roeper Review, 27, 158-163. doi:10.1080/02783190509554310

Barron, F. (1988). Putting creativity to work. In R.J. Sternberg (Ed.), The Nature of Creativity (pp. 76-98). New York: Cambridge University Press.

Bassok, M., Chase, V. M., \& Martin, S. A. (1998). Adding apples and oranges: Alignment of semantic and formal knowledge. Cognitive Psychology, 35, 99-134. doi:10.1006/cogp.1998.0675

Bonk, C. (2003). Creativity tests: Guilford's alternative uses task (1967). Indiana University: school of education: department of educational psychology. URL

http://www.indiana.edu/ bobweb/Handout/sub/Bob_CT_Uses.html

Briskman, L. (1980). Creative product and creative process in science and art. Inquiry, 23, 83-106. doi:10.1080/00201748008601892

Besemer, S. P., \& O'Quin, K. (1993). Assessing creative products: Progress and potentials. In S. G. Isaksen, M. Murdock, R. Firestien, \& D. Treffinger (Eds.), Nurturing and developing creativity: The emergence of a discipline (pp. 331-349). Norwood, New Jersey: Ablex Publishing Corp.

Bull, K. S., Montgomery, D., \& Kimball, S. L. (1999). Stimulating creativity in online teaching: An instructional hypertext. Stillwater, OK: Oklahoma State University. URL

http://home.okstate.edu/homepages.nsf/toc/EPSY5213 Reading_11b

Davidson, J. E. (1986). Insight and giftedness. In R. J. Sternberg, \& J. E. Davidson (Eds.), Conceptions of giftedness (pp. 201-222). New York: Cambridge University Press.

Davidson, J. E., \& Sternberg, R. J. (1984). The role of insight in intellectual giftedness. Gifted Child Quarterly, 28, 58-64. doi:10.1177/001698628402800203

Dover, A., \& Shore, B. M. (1991). Giftedness and flexibility on a mathematical set-breaking task. Gifted Child Quarterly, 35, 99-105. doi:10.1177/001698629103500209

El-Murad, J. \& West, D. C. (2004). Definition and measurement of creativity: What do we know? Journal of Advertising Research, 44, 188-201. doi:10.1017/S0021849904040097

Feldman, D.H. (1999). The development of creativity. In R. J. Sternberg (Ed.), Handbook of creativity (pp. 169-186). New York: Cambridge University Press.

Gentner, D., Loewenstein, J., \& Thompson, L. (2003). Learning and transfer: A general role for analogical encoding. Journal of Educational Psychology, 95, 393-408. doi:10.1037/0022-0663.95.2.393

Gentner, D., Brem, S., Ferguson, R., Wolff, P., Markman, A., \& Forbus, K. (1997). Analogy and creativity in the works of Johannes Kepler. In T. Ward, S. Smith, \& J. Vaid (Eds.), Creative Thought: An Investigation of Conceptual Structures and Processes, (pp. 403-459). Washington DC: American Psychological Association. doi:10.1037/10227-016

Gorodetsky, M., \& Klavir, R. (2003). What can we learn from how gifted/average pupils describe their processes of problem solving? Learning and Instruction, 13, 305-325. doi:10.1016/S0959-4752(02)00005-1

Guilford, J. P. (1967). The Nature of Human Intelligence, New York:
McGraw-Hill Book Company.

Hennessey, B. A. (2004). Developing creativity in gifted children: The central importance of motivation and classroom climate (RM04202). Storrs, CT: The National Research Center on the Gifted and Talented, University of Connecticut.

Hennessey, B. A., \& Amabile, T. M. (1988). Storytelling: A method for assessing children's creativity. Journal of Creative Behavior, 22, 235-246.

Karimi, Z., Windmann, S., Güntürkün, O., \& Abraham, A. (2007). Insight problem solving in individuals with high versus low schizotypy. Journal of Research in Personality, 41, 473-480. doi:10.1016/j.jrp.2006.03.008

Klavir, R., \& Gorodetsky, M. (2009). On excellence and creativity: A study of gifted and expert students. In R. Leikin, A. Berman, \& B. Koichu, (Eds.). Creativity in mathematics and the education of gifted students. (pp. 221-242). SENSE Publisher Exhibition.

Klavir, R., \& Gorodetsky, M. (2001). The encounter of gifted/nongifted students with cartoons and their analogical verbal problems. Gifted Child Quarterly, 45, 205-215. doi:10.1177/001698620104500305

Klavir, R., \& Hershkovitz, S. (2008). Teaching and evaluating 'openended' problems. International Journal for Mathematics Teaching and Learning. URL http://www.cimt.plymouth.ac.uk/journal/default.htm

Kleiman, P. (2005). Beyond the tingle factor: Creativity and assessment in higher education. Paper presented at the ESRC Creativity Seminar, University of Strathclyde, 7 October 2005.

http://opencreativity.open.ac.uk/assets/pdf/strathclyde/Beyond\%20th e\%20Tingle\%20Facto.pdf

Lake, A. (1976). The Puzzle Book. New York: Hart Publishing.

Martindale, C. (1999). Biological bases of creativity. In R. Sternberg, (Ed.), Handbook of creativity (pp. 137-152). Cambridge: University Press.

Milgram, R. M., \& Livne, N. (2006). Research on creativity in Israel: A chronicle of theoretical and empirical development. In J. C. Kaufman, \& R. J. Sternberg (Eds.), The international handbook of creativity (pp. 307-336). New York: Cambridge University Press.

Mulhern, J. D. (2003). The gifted child in the regular classroom. Roeper Review, 25, 112-115. doi:10.1080/02783190309554211

Mumford, M. D. (1998). Creative thought: Structure, components and educational implications. Roeper Review, 21, 14-19. doi:10.1080/02783199809553920

Mumford, M. D., Decker, B. P., Connelly, M. S., Osburn, H. K., \& Scott, G. (2002). Beliefs and creative performance: Relationships across three tasks. The Journal of Creative Behavior, 36, 153-181.

Nevo, B. (1997). Creativity. In B. Nevo (Ed.), Human intelligence (pp. 635-686). Tel Aviv: The open university of Israel. (Hebrew).

Planche, P. (1985). Modalités fonctionnelles et conduites de résolution de problème chez des enfants précoces de 5 , 6 et 7 ans d'âge chronologique. Archives de Psychologie, 53, 411-415.

Reiter-Palmon, R., Mumford, M. D., O’Connor B. J., \& Runco, M. A. (1997). Problem construction and creativity: The role of ability cue consistency and active processing. Creativity Research Journal, 10, 9-23. doi:10.1207/s15326934crj1001_2

Renzulli, J. S. (1998). The three-ring conception of giftedness. In S. M. Baum, S. M. Reis, \& L. R. Maxfield (Eds.), Nurturing the gifts and talents of primary grade students. Mansfield Center, CT: Creative Learning Press. URL

http://www.gifted.uconn.edu/sem/semart13.html

Rex, L. (1996). A theory of conceptual intelligence: Thinking, learning, creativity and giftedness. Westport, C.T: Praeger Publishers.

Rogers, K. B. (2002). Re-forming Gifted Education: Matching the Program to the Child. Scottsdale, AZ: Great Potential Press Inc.

Rogers, M. T., \& Silverman, L. K. (1998). Recognizing giftedness in young children. Eric Clearinghouse on Handicapped and Gifted Children. ED428471. URL

http://www.eric.ed.gov/ERICDocs/data/ericdocs2sql/content_storage 01/0000019b/80/25/ae/96.pdf

Runco, M.A. (2005). Creative giftedness. In R. J. Sternberg, \& J. E. 
Davidson (Eds.), Conceptions of giftedness (2nd ed., pp. 295-311). New York: Cambridge University Press. Washington DC: American Psychological Association.

Runco, M.A. (2007). Creativity: Theories and themes: Research, development and practice. Amsterdam, Boston: Elsevier Academic Press.

Schunk, D.H., \& Pajares, F. (2005). Competence perceptions and academic functioning. In A. J. Elliott, \& C. S. Dweck (Eds.), Handbook of competence and motivation (pp. 85-104). New York: Guilford Press.

Shye, S., \& Goldzweig, G. (1999). Creativity as an extension of Intelligence: Faceted definition and structural hypotheses. Megamot, 40, 31-53. (Hebrew).

Sternberg, R. J., \& Lubart, T. I. (1996). Investing in creativity. American Psychologist, 51, 677-688. doi:10.1037/0003-066X.51.7.677

Sternberg, R. J., \& Lubart, T. I. (1999). The concept of creativity: Pros- pects and paradigms. In R. J. Sternberg (Ed.), Handbook of creativity. Cambridge: University Press.

Tannenbaum, A. J. (1983). Gifted children: Psychological and educational perspectives. New York: Macmillan.

Torrance, E. P. (1972). Torrance tests of creative thinking normstechnical manual. Bensenville, Illinois: Scholastic Testing Service.

VanTassel-Baska, J. (2001). Creativity as an elusive factor in giftedness. New Zealand Journal of Gifted Education, 13, 33-37.

Ward, T. B., Saunders, K. N., \& Dodds, R. A. (1999). Creative cognition in gifted adolescents. Roeper Review, 21, 260-265. doi:10.1080/02783199909553973

Winner, E. (1997). Exceptionally high intelligence and schooling. American Psychologist, 52, 1070-1081. doi:10.1037/0003-066X.52.10.1070

Winner, E. (2000). The origins and ends of giftedness. American Psychologist, 55, 159-169. doi:10.1037/0003-066X.55.1.159

\section{Appendix 1}

\section{The Source Problems}

\section{The Insight-Non-Mathematical (Verbal) Problem}

Mr. Keidar was the manager of the Sun Furniture Factory. On Wednesday, at a management meeting, it was decided that Mr. Keidar would travel to Amsterdam to sign a contract that had recently been drawn up. The office staff heard about this plan, and their gossip about this development leaked out, eventually finding its way to the ears of Sammy Cohen, the factory's night watchman. Panic-stricken, Sammy hurried to the office the next morning to meet with Mr. Keidar face-to-face.

"Mr. Keidar!" said Sammy, "I heard that you are going to Amsterdam. Don’t do it! Please, Mr. Keidar, don’t do it! I had a terrible dream! I dreamed about your trip to Amsterdam all night long. In my dream, someone came up and shot you to death.”

At that moment, the secretary came in and told Mr. Keidar that if he wanted to be on time, he would have to hurry to Ben Gurion Airport. Mr. Keidar paid no attention to his night watchman's dream, and traveled to Amsterdam, as planned.

A week later, Mr. Keidar returned from Amsterdam safe and sound, with the contract signed. The first thing he did upon returning to his office was to fire Sammy Cohen. Who made a mistake here, and what was the mistake that led Mr. Keidar to fire Sammy Cohen?

\section{The Mathematical Problem}

French, English, and Hebrew books were purchased for the new library that was constructed next to the municipality building. The Hebrew books, which comprised 3/5 of the total number of books, were arranged on shelves on the ground floor. The French books, which comprised $15 \%$ of the total, were arranged on shelves on the top floor. The English books, which comprised 3,500 fewer titles than the Hebrew books, were arranged on shelves on the middle floor. The average cost of a Hebrew book was 5 shekels. The cost of a French book was 20 shekels, whereas the cost of an English book was 10 shekels. What was the total cost of all the books purchased for the new library?

\section{The Insight-Mathematical Problem}

Oded, Ronnie, and Yair were tired and hungry after playing football. They saw a restaurant on the corner, and went inside. Oded ordered 10 buns, Ronnie ordered 8, and Yair, who was the smallest, ordered only 6 . Each of them paid for his order, and they sat down together for the meal.

Suddenly, their cousin Youval showed up. He came directly from swim practice and was also hungry. Oded, Ronnie, and Yair invited Youval to sit down with them and to share their buns with him, equally. Youval agreed, and they split the buns equally among the four cousins.

When they had finished eating and chatting about sports, Youval took out 24 shekels to cover the cost of his buns and 
hurried home. Oded, Ronnie, and Yair wondered how to divide the 24 shekels among themselves in the fairest way.

\section{Appendix 2}

\section{Examples for the Way of Analysis of a New Constructed Insight-Non-Mathematical (Verbal) Problem}

\section{An Explained Example}

A woman employed a nanny who took care of her baby every day until she returned home from work. One day the woman told her nanny that she wanted to go on vacation for a few days. The next day the nanny advised the woman not to go on vacation because the previous day, while the baby was asleep and she was cleaning the neighbours' apartment, she heard on the news that there was going to be a heat wave the coming weekend.

The woman immediately fired the nanny and deducted a certain amount from her salary. Who made a mistake here and what is the nature of the mistake?

1) Flexibility - high (different content and context): The background to the story is different than the one in the original problem (at home and relating to a nanny's job replacing the furniture factory). The content variables are different: Instead of failing in the duties of a night watchman, the new situation addresses the nanny's failure to perform her duties. The reason for the journey was changed from business to vacation, and the cause for postponing the journey was changed from assassination to a heat wave.

2) Appropriateness - high (relevant solution structure): Both stories deal with workers that expose, unconsciously, their misbehavior at work and consequently are dismissed by their employers.

3) Elaboration-high (different solution structure): The solution structure is not only relevant, but has also been restructured meaningfully. Both stories deal with workers who unconsciously expose their misbehaviour at work and are consequently dismissed by their employers. In addition, the deep structure of the new problem is restructured meaningfully and was removed from that of the source problem: the employer (person $\mathrm{B}$ in the scheme below) deducted the payments from the salary of the nanny (person A). The extended parts of the deep structure of the solution are depicted in bold letters in the scheme below.

4) Originality - high (very original): This was determined to be high on originality since the majority of the judges identified this problem as being unusual and unexpectedly unique in comparison to the other newly constructed problems.

\section{Some Additional Examples for the Analysis Process of the Insight-Verbal New Constructed Problems}

1) One day, Rami, a night watchman at a cookie factory, heard that his manager, Mister "Cookie", intended to travel to Switzerland to clinch a deal in the realm of chocolates. Rami rushed to ask him not to go because he had dreamed at night
A scheme.

Comparison between the solution structure of the source problem and the solution structure of the new constructed problem.

\begin{tabular}{|c|c|}
\hline $\begin{array}{l}\text { The solution structure of the } \\
\text { source problem: }\end{array}$ & $\begin{array}{l}\text { The solution structure of the } \\
\text { new constructed problem: }\end{array}$ \\
\hline $\begin{array}{l}\text { If } \\
\text { the duty of person A is to exe- } \\
\text { cute X, } \\
\text { And if, } \\
\text { person B is responsible, that } \\
\text { person A will execute X, } \\
\text { And if, } \\
\text { person A does not execute X, }\end{array}$ & $\begin{array}{l}\text { If } \\
\text { the duty of person A is to execute } \\
\mathrm{X} \text {, } \\
\text { And if, } \\
\text { person } \mathrm{B} \text { is responsible, that per- } \\
\text { son A will execute } \mathrm{X} \text {, } \\
\text { And if, } \\
\text { person A does not execute } \mathrm{X} \text {, } \\
\text { And if, } \\
\text { person A receives payment for } \\
\text { executing } \mathrm{X} \text {, and also for another } \\
\text { job that is executed during the } \\
\text { same time he was to execute } \mathrm{X} \text {, }\end{array}$ \\
\hline $\begin{array}{l}\text { And if, } \\
\text { he himself tells that to person B, } \\
\text { Then, } \\
\text { person B knows that person A is } \\
\text { not performing his duty and may } \\
\text { dismiss him. }\end{array}$ & $\begin{array}{l}\text { And if, } \\
\text { he himself tells that to person B, } \\
\text { Then, } \\
\text { person B knows that person A is } \\
\text { not performing his duty and may } \\
\text { dismiss him. } \\
\text { In addition, } \\
\text { person B can deduct the payments } \\
\text { from the salary of person A. }\end{array}$ \\
\hline
\end{tabular}

that someone would murder him in Switzerland. In order to convince the manager, he added that the secretary shared his opinion. He told the manager that the secretary had told him that two days before, when he, the manager, was out of the factory, she had gone out to buy clothes, and she met someone who told her about a friend of his who had been murdered in Switzerland. The manager went to Switzerland and signed the deal. When he returned he fired the night watchman and the secretary. Why?

Flexibility: identical; Appropriateness: relevant; Elaborateness: different; Originality: Partially-original.

2) A mechanic told his boss, the garage manager, that the car that had been brought in for repair had already been checked by him, and he had not found any mechanical problems. The manager took the car and went to test it. When he came back, he told the mechanic that he had found many mechanical problems, and fired him immediately. Why?

Flexibility: different; Appropriateness: irrelevant; Elaborateness: Originality: not-original

3) In a hospital in the north, a physician was in charge of the emergency room during the weekends. One day he heard that Dr. Levi, the hospital manager, had to travel to Cairo to take part in the International Medical Committee meeting there. The ER doctor hurried to his boss, Dr. Levi, and tried to convince him not to travel to Cairo because the previous Saturday, while eating lunch in a restaurant with his family, he heard that it was very dangerous in Cairo. Despite the story, Dr. Levi attended the meeting. When he returned, he replaced the ER doctor during weekends. Was this act justified?

Flexibility: different; Appropriateness: relevant; Elaborateness: identical; Originality: partially-original. 